\title{
Benzoporphyrin(Verteporfin) Photodynamic Therapy for Choroidal Neovascularization in Age-Related Macular Degeneration
}

\author{
Terapia fotodinâmica de neovascularização decoróide por degeneração macular \\ relacionada à idadecom benzoporfirina (verteporfirina)
}

Evandro G. Lucena ${ }^{(1)}$

Joan W. Miller ${ }^{(2)}$
Laser Research Laboratory - Retina Service, Massachusetts Eye and Ear Infirmary; Harvard Medical School, 243 Charles St. 12 ${ }^{\text {th }}$ Floor-Boston, MA 02114 Research Fellow - Massachusetts Eye and Ear Infirmary - Harvard Medical School.

2) Associate Professor of Ophthalmology - Massachusetts Eye and Ear Infirmary - Harvard Medical School Financial disclosure: The Massachusetts Eye and Ear Infirmary is an owner of a patent covering the use of Verteporfin (benzoporphyrin). Should the Massachusetts Eye and Ear Infirmary receive royalties or other financial remuneration related to that patent, Dr. Miller would receive a share of same in accordance with the Massachusetts Eye and Ear Infirmary's institutional Patent Policy and Procedures, which includes royalty-sharing provisions. As a faculty member of the Harvard Medical School, I also adhere to their general Faculty policies on Integrity in Science which govern research and conflict of interest issues.

Address correspondence to: Evandro G. Lucena, Jr. M. D. - Rua Macedo Sobrinho 45/406, Rio de Janeiro (RJ) Brazil. CEP 22271-080. E-mail:lucena@iname.com

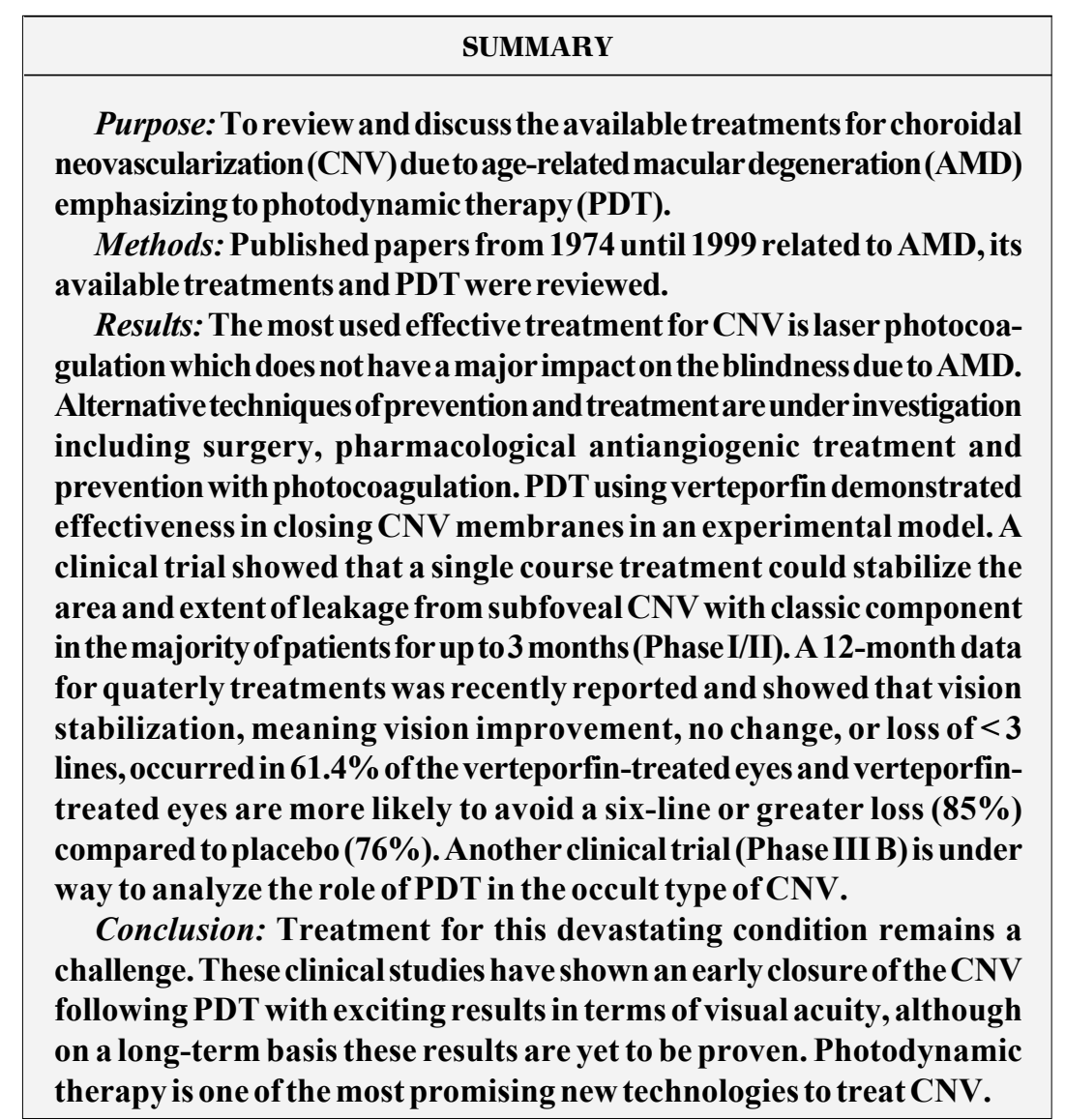

Keywords: Photodynamic therapy; Age-related macular degeneration; Choroidal neovascularization.

\section{INTRODUCTION}

Age related macular degeneration (AMD) is the leading cause of severe visual impairment and legal blindness in elderly people in most industrialized countries ${ }^{1-7}$. This degenerative disorder is a broad-spectrum disease ranging from an early dry form with drusen and retinal pigment abnormalities and minimal or unaffected visual function to a late dry stage of geographic atrophy and marked visual loss or a wet or neovascular form characterized by choroidal neovascularization and fibrous scarring of the macula with severe vision loss. 
The vast majority (79\%) of patients with age-related macular degeneration usually present a slow-developing atrophic form of AMD and $5.3 \%$ of cases of AMD have the rapidly evolving neovascular form ${ }^{9}$. Although the atrophic form has a higher prevalence, neovascular form accounts for $79 \%$ to $90 \%$ of legal blindness due AMD ${ }^{8,9}$. It is present in $6.4 \%$ of population between 64 and 75 years of age and in $19.7 \%$ of the population over 75 years of age ${ }^{7-9}$. Furthermore, if one eye is affected and the second eye has evidence of risk factors for neovascular disease (i.e.:large soft drusen and pigmentary abnormalities), approximately $4 \%$ to $12 \%$ of patients will develop neovascular disease in the fellow eyes each year ${ }^{10-12}$.

Choroidal neovascularization due to AMD is a pathological process in which blood vessels grow beneath the retina and leak fluid, blood and lipids. This process results in scarring, which may disrupt the integrity of the macula with associated visual loss ${ }^{13}$. Based on fluorescein angiogram findings and fundus photographs there are 2 types of choroidal neovascular membranes: well-demarcated areas of hyperfluorescence revealing the neovascular process itself in the early phase of the angiogram characterize the classic type. In the occult type, 2 forms of lesion are recognized: the fibrovascular pigment epithelial detachment and the latephase leakage of undetermined source. In this occult type the neovascular complex is not demarcated but the diffuse leakage of dye derived from it in the early and late phases of the angiogram ${ }^{14-16}$.

\section{Available treatments for AMD}

Laser photocoagulation is until now the most used effective treatment for CNV. For patients who have extrafoveal or juxtafoveal well-defined CNV, laser photocoagulation is better than no treatment for preventing or delaying large losses of visual acuity ${ }^{17-20,30}$. Laser treatment for eligible patients with sub foveal $\mathrm{CNV}$, both new and recurrent lesions may lead to severe destruction of the sensory retina with significant visual loss. Data from the Macular Photocoagulation Studies (MPS) demonstrated that laser treated eyes are less likely to suffer severe visual loss than control eyes in selected cases, but many retinal specialists are reluctant to treat subfoveal $\mathrm{CNV}$ because of the acute visual loss associated with the foveal photocoagulation right after the procedure ${ }^{21-25}$. Unfortunately, the majority of the patients, up to $87 \%$ of them, with newly diagnosed neovascular AMD accordingly to Freund et al. ${ }^{26}$, do not meet the criteria for laser photocoagulation because the CNV is too large, occult or ill defined $14,15,27,28$. Furthermore, among those patients with extrafoveal lesion treated with laser photocoagulation, up to $54 \%$ suffered recurrence (defined by leakage of fluorescein at the periphery of the laser scar later than 6 weeks after treatment) after a 5 -year follow-up ${ }^{18,30,31 .}$ In the juxtafoveal and subfoveal groups of patients similarly recurrence occurred in 47 and $35 \%$ respectively $27,32,34$. Nowadays, it is becoming evident that the available techniques for laser photocoa- gulation of choroidal neovascular membranes due to AMD will not have a major impact on blindness due to AMD, despite early expectations ${ }^{24,27,34,35}$.

Prevention therapy with laser photocoagulation of soft drusen emerged as an alternative form of treatment, evaluated by a series of clinical trials ${ }^{36-40}$. Despite the initial observation that laser photocoagulation could cause large soft drusen to disappear, (which have been showed to be high risk for $\mathrm{CNV}^{11,12,41}$ ), a large randomized, multicenter trial (Choroidal Neovascularization Prevention Trial) revealed that laser treatment to high risk eyes may increase the shortterm incidence of $\mathrm{CNV}{ }^{40,44}$. A NIH-sponsored multicenter trial is now under way to evaluate the actual role of laser treatment in the disappearance of drusen.

Submacular surgery for the removal of the CNV has been used for eyes with CNV secondary to AMD and other diseases ${ }^{45-47}$. CNV membrane removal in AMD patients appears to be associated with removal of native RPE cells and photoreceptors leading to loss of visual function ${ }^{48}$. Furthermore, there is a high-rate of recurrences (up to $46 \%$ ) and complications ${ }^{47,49-51}$. A large multicenter NIH-sponsored randomized trial (Submacular Surgery Trial) is currently recruiting patients in the US and will reveal the actual role of the submacular surgery in the treatment of the CNV due to AMD. Alternative modalities of surgery are being investigated including macular translocation and macular transplantation ${ }^{52-57}$

Radiotherapy is considered as an antiangiogenic and antiinflammatory modality. Chakravarthy et al. were able to demonstrate in a pilot study that external beam radiation could maintain central vision and induce regression of actively growing choroidal neovascular membranes ${ }^{58}$. In addition, Bergiink et al. demonstrated in a well-controlled randomized study that treated patients were more unlikely to suffer severe visual loss than untreated patients (32 and $40 \%$ respectively) ${ }^{59}$. Similarly, Finger et al. showed relatively good results of episcleral plaque brachytherapy with palladium 103 in controlling the growth of $\mathrm{CNV}{ }^{60}$. However, Spaide et al. in a nonrandomized multicenter study and Stalmans et al. reviewing 111 cases of patients submitted to radiotherapy found that external beam radiation failed to control or induce regression of active growing $\mathrm{CNV}{ }^{61,62}$. Inclusion criteria and variable follow up, different radiation types, rate of administration and doses make comparison and evaluation of the results difficult. In fact, critical analysis reveals that the efficacy of these treatments as compared to natural history remains uncertain and clinical trials are under way in the US and in the UK to investigate the efficacy of the radiation in the treatment of neovascular AMD.

Pharmacological antiangiogenic treatment holds great promises. Drug therapy would enable us to avoid the deleterious effects of laser photocoagulation on the delicate macular tissue. Interferon alpha-2a has been shown to be effective as an antiangiogenic drug for several systemic disorders and experimentally caused regression of iris 
neovascularization in a experimental monkey model ${ }^{63-65}$. However, in a multicenter randomized clinical trial with 481 patients from all over the world (Pharmacological Therapy for Macular Degeneration Group) interferon alpha-2a showed to be of no benefit for CNV secondary to AMD ${ }^{65}$. Further research is needed to establish the role of drugs such as thalidomide, VEGF-inhibitors, steroids, angiostatin and endostatin, which share antiangiogenic effects and have the potential to halt the progression of neovascularization ${ }^{66-74}$.

\section{Photodynamic Therapy}

Photodynamic therapy is an attractive and innovative modality of treatment for a number of diseases. It utilizes an exogenous photosensitizing agent, which localizes the target tissue and is subsequently excited by a specific wavelength, generating highly reactive compounds that lead to cell damage and death.

The use of an exogenous sensitizer for a therapeutic effect started approximately 1500 years ago when phototherapeutic techniques for treatment of vitiligo were developed using psoralens obtained from the seeds of Psoralia corifolia in ancient India and from leafs of Amni majus by the Egyptians ${ }^{75,76}$. Von Tappeiner and Oscar Raab in Munich developed however the use of sensitized oxygen-requiring reactions in the early 1900s in a classical example of serependity in science. While studying the toxic properties of acridine to Paramecium, a strong thunderstorm occurred during one of the experiments creating distinctly different light conditions and the exposed Paramecia died. They found that acridine even in small concentrations combined with light exposure increased the toxicity against the Paramecia. Von Tappeiner took over Raab's research and with a dermatologist named Jestoniek developed photodynamic techniques for therapy of skin diseases such as molluscum contagiosum, ptyriasis versicolor and psoriasis. Two years later skin cancer, lupus and chondylomata were been investigated using eosin as a photosensitizer ${ }^{75,76}$.

In its modern era, photodynamic therapy began with studies at the Mayo Clinic by R. Lipson and S. Schwartz in 1960 using hematoporphyrin as a fluorescent dye to detect cancer cells ${ }^{77}$. It has been proved useful for a variety of malignant and non-malignant diseases ${ }^{77-81}$. In 1993 PDT using Photofrin was approved by a health agency for the first time in Canada, for treatment of bladder cancer. Subsequently approvals were obtained in France, Germany, The Netherlands, Japan and USA. It is being used for treatment of early and latestage gastrointestinal cancers, bladder cancers, lung cancers and with pending approvals for other cancers in a number of countries worldwide ${ }^{80,82,83}$. A wide variety applications are being tested such as therapy of microbial infections, skin disorders, psoriasis and ocular disorders including tumors and choroidal neovascular membranes ${ }^{77,78,80,81-90}$.

\section{Mechanism of Action}

Following the administration of the photosensitizer dye, there is a selective retention of the drug in the target tissue. Photosensitive dyes are preferentially retained in tumors or more specifically in neovascular tissue of tumors due to characteristic aspects of the photosensitize, of the cellular membrane and mechanisms of transport of macromolecules of these pathologic cells, which allows selective treatment ${ }^{92-95}$.

The target cells are then light irradiated and the molecules of the dye gain energy passing from the ground state to an excited, highly reactive, short-lived triplet state which transfers the excess of energy by two pathways:

1) The energy absorbed from the triplet state is transferred to other molecules leading to the generation of free radicals, which instantaneously oxidize a wide variety of biomolecules - Type I mechanism.

2) The energy absorbed from the triplet state is transferred to oxygen generating high reactive short-lived oxygen - Type II mechanism which appears to play the major role in the effect seen in PDT ${ }^{96}$.

The interactions of these highly reactive compounds cause cellular and vascular damage. Cellular membranes including plasma and nuclear membranes are severely damaged by photo-oxidation of fatty acids and cholesterol ${ }^{97}$. The permeability of the damaged membrane results in a rapid derangement of the cellular homeostasis. In addiction there is cross-linking of proteins responsible for the transport mechanisms and structural maintenance with release of $\mathrm{Na}^{+}$, $\mathrm{K}^{+}$, and $\mathrm{Ca}^{++}$and direct damage to the nuclear DNA ${ }^{98-100}$.

The release of all of these physiologically active ions has been associated with an immediate induction of acute inflammatory responses: Liberation of phospholipids induces arachidonic acid cascade, thromboxane, prostaglandin and leukotriene synthesis, platelet aggregation, release of histamine, serotonin and bradykinin increasing the effects of eicosanoids and activation of the complement cascade inducing response from the immune system, leading to acute inflammation and edema (vascular response) and therefore, occlusion of the feeding vessels ${ }^{98,101}$.

\section{BPD-MA or verteporfin}

BPD-MA or verteporfin (a benzoporphyyrin derivative) is a second generation potent photosensitizer of the tetrapyrrole group that is currently being investigated for its antineoplastic and anti-neovascular properties as well as for its properties regarding destruction of neovascular tissue as well as tumors in ophthalmology ${ }^{90,91}$. It absorbs light at $690 \mathrm{~nm}$. A longer wavelength is important because it allows deep tissue penetration, through blood, pigments and fluid which could accumulate beneath the retina. Plasma half-life ranges approximately from 5 to 6 hours and BPD-MA/Verteporfin is excreted mainly by the bile (90\%). It is administered intravenously as a liposomal preparation and partitions into the LDL phase of the lipoprotein fraction of the blood ${ }^{94,102}$. Endothelial cells which form the neovessels of tumors and neovascular membranes have been shown to have increased the popula- 
tion of LDL receptors that play a major role in the mechanism of the uptake and therefore the selectivity of the photosensitizer in these cells ${ }^{94}$. It has been shown to be safe for human use and was first used in dermatology for treatment of malignant lesions of the skin ${ }^{89}$.

\section{Preclinical studies}

PDT using verteporfin for treatment of $\mathrm{CNV}$ has been extensively investigated in a monkey model of choroidal neovascularization. In these studies, laser burns in the macula of the monkeys induced the CNV ${ }^{103-109}$.

Studies have been demonstrated the in vivo localization of verteporfin in the cells relevant to CNV (i.e. RPE cells and capillary endothelial cells). Haimovici et al. were able to demonstrate the localization of BPD-MA/verteporfin in RPE and choroid within 5 minutes after the injection of the dye and in outer segments after 20 minutes in rabbit eyes ${ }^{103}$. Using digital quantitative analysis of fluorescence, Miller et al. were able to show the selective accumulation of verteporfin in CNV membranes of patients and in experimental CNV membranes created in the maculae of monkeys using high intensity laser burns ${ }^{104}$.

The effectiveness, selectivity and safety of PDT using verteporfin were assessed in these models which demonstrated effective closure of the CNV membranes, documented by histopathological examinations, fundus photography and fluorescein angiography. Further evaluation on dosimetry included verteporfin dose, infusion time, light dosimetry, timing of irradiation and long-term follow up ${ }^{105-109}$.

\section{Clinical Trials}

Based on these preclinical studies a multicenter, nonrandomized, phase I/II trial started in 1995 sponsored by QLT Phototherapeutics and CIBAVision Ophthalmics to investigate the effectiveness and dosimetry of BPD-MA ${ }^{111}$.

Patients with subfoveal CNV with some classic component, lesion with less than 9 MPS disc areas and refracted visual acuity of 20/40 or worse were enrolled to participate in the trial. Pretreatment examination included best refracted visual acuity by protocol, standardized fluorescein angiogram and fundus photographs (when eligibility criteria were confirmed by the reading center), medical evaluation which included a medical examination, EKG, liver function tests and complete blood count and informed consent 112,114,115.

The patients were followed-over 3 months with refracted visual acuity, ophthalmic examination and standardized fundus photography and fluorescein angiogram. A total of 128 patients with subfoveal CNV secondary to AMD were enrolled in dose-escalating regimens, using a verteporfin dose of 6 or $12 \mathrm{mg} / \mathrm{m}^{2}$, and a light dose of $12.5-150 \mathrm{~J} / \mathrm{cm}^{2}$ and 600 $\mathrm{mW} / \mathrm{cm}^{2}$, with irradiation applied 10,20 or 30 minutes after the start of verteporfin infusion. Ninety-seven patients were enrolled and received a single treatment with a planned 3months follow-up. Additional 31 patients were enrolled in retreatment protocols, at 2- or 4-week intervals. Thirteen non-
AMD patients were also enrolled and were analyzed separately. Most cases showed absence of leakage from classic CNV at 1 week of follow-up, consistent with occlusion of the CNV. Complete absence of leakage from classic CNV occurred in 52$100 \%$ of the patients at week 1 , depending on the regimen. By 4 weeks of follow-up, most patients showed leakage from a part of the original area of classic CNV. At 12 weeks of followup, extension of the CNV beyond the original border, was seen in some cases. Increasing the verteporfin or light does did not prevent this reappearance of leakage, and non selective effects, namely retinal vessel non perfusion was seen at the highest light dose, and defined the acceptable upper limit of the light dose.

In the single treatment of AMD patients, the mean visual acuity change at 1 week was +0.7 lines. Interestingly, 18 patients $(14 \%)$ showed vision improvement of $>3$ lines. By week 4 , the visual acuity change was +0.2 , and by week 12 , it was -0.5 lines. One regimen gave somewhat better results regarding visual acuity and angiographic leakage and was selected for the phase 3 trial. Multiple treatments were tolerated without any short-term loss of vision due to retreatment. Results from the phase I/II trial also showed a promising response to the treatment of patients with $\mathrm{CNV}$ secondary to pathologic myopia stabilizing the visual acuity and extent of the lesion ${ }^{111-116}$.

This study showed that a single course of treatment could safely stabilize the area and extent of leakage from CNV lesions in the majority of patients for up to 3 months. Since the size and activity of the lesion has a close relation to visual acuity, these results supported the rationale for the phase III studies to evaluate the safety and efficacy of quarterly treatments of CNV stabilizing the visual acuity of such patients ${ }^{115-116}$.

Phase IIIA trial started in December 1996 as a randomized, controlled, masked multicenter study involving approximately 18 centers (TAP study). The eligibility criteria for this study included subfoveal CNV secondary to any cause with a classic component demonstrable by fluorescein angiography and with an area of less than 9 MPS disc areas. Visual acuity had to be worse than $20 / 40$ but equal to or better than $20 / 200$.

Pretreatment evaluation included best-refracted visual acuity, ophthalmic examination, standardized fundus photography fluorescein angiogram and medical evaluation (EKG, laboratory tests, complete blood count and liver function tests).

By 1997, 609 patients had been enrolled by the 22 participating centers. Patients underwent refracted visual acuity, ophthalmic examination, and standardized fluorescein angiography at enrollment, and were randomly assigned $(2: 1)$ to PDT with verteporfin or PDT with D5W (placebo). Patients underwent irradiation of the macula with $690 \mathrm{~nm}$ laser light 15 minutes after the start of verteporfin or placebo infusion, using $50 \mathrm{~J} / \mathrm{cm}^{2}$ and $600 \mathrm{~mW} / \mathrm{cm}^{2}$. They returned at 3-month intervals and underwent protocol refraction, ophthalmic examination, and fluorescein angiography. Retreatment was per- 
formed if leakage was demonstrated angiographically. The study was designed to determine whether PDT using verteporfin could reduce the risk of severe visual loss from subfoveal $\mathrm{CNV}$ in AMD, with the primary endpoints being of $>3$ lines of vision lost and $>6$ lines lost. Secondary endpoints include contrast sensitivity, mean visual acuity loss, and angiographic leakage.

An interim report of the 12-month data was recently reported, showing vision improvement, no change, or loss of $<3$ lines, occurred in $61.4 \%$ of the verteporfin-treated group and $45.9 \%$ of the placebo, while vision improvement of $>1$ line occurred in $16 \%$ of that group compared to $7 \%$ of the placebo group. Eyes treated with verteporfin were more likely to avoid a six-line or greater loss (85\%) when compared to those with placebo (76\%). Based on estimates from Kaplan-Meier rates, at every follow-up examination after study entry, the proportion of eyes with $>3$ line loss or $>6$ line loss was less in the verteporfin-treated group. The mean number of contrast sensitivity letters lost was approximately one in the verteporfin-treated eyes compared to approximately three to five in placebo-treated eyes in every follow-up visit at the 12-month examination. Some subgroup analyses have also been performed. When the entire study population was separated by the presence or absence of occult $\mathrm{CNV}$, the subgroup with no occult CNV had a substantial treatment benefit. Specifically, $23 \%$ of the verteporfin-treated eyes compared to $73 \%$ of the placebo-treated eyes had lost $>3$ lines of vision. If occult CNV was present, $45 \%$ of the verteporfin-treated eyes compared to $47 \%$ of the placebo-treated eyes lost $>3$ lines. A substantial treatment benefit was also seen when $>50 \%$ of the lesion area was classic CNV. Other secondary endpoints like lesion growth also favored the verteporfin-treated group. By the month 12 examination, verteporfin-treated patients received an average of 3.4 treatments per subject compared to 3.7 treatments per subject for placebo-treated patients. Treatments were well tolerated with $<2 \%$ withdrawing because of adverse events. Photosensitivity reactions occurred in $2 \%$ of the participants, and resolved within 24 hours ${ }^{117}$.

Another phase 3 trial using verteporfin PDT for CNV was initiated in 1998, enrolling patients with subfoveal CNV secondary to AMD with occult-only components, and subfoveal CNV secondary to pathologic myopia. Known as VIP (Verteporfin In Photodynamic therapy), the study had over 400 patients enrolled as of September, 1998, and follows the same treatment protocol as TAP.

These clinical studies have shown an early closure of the CNV following PDT with exciting results in terms of visual acuity, although on a long-term basis these results are yet to be proven. Reopening of the lesion with leakage of dye in the angiogram was very common and required reapplication. At the present, photodynamic therapy is the most effective and less damaging treatment for neovascular CNV. New dyes and lasers have been tested in a number of experimental trials including tin-ethyl etiopurpurin (Purlytin) and lutetium texaphrin (Lu-Tex), and further research is needed to determine the most appropriate photosensitizer and laser for PDT in ophthalmology. In the very near future the approach to the treatment of this blinding disease is going to be changed dramatically with improvement of Photodynamic Therapy which could be used in a multifaceted aspect of treatment associated with pharmacologic inhibition of angiogenesis, conventional laser, ocular surgery and other modalities of treatments.

\section{RESUMO}

Objetivo: Rever e discutir os tratamentos disponiveis para neovascularização subrretiniana (CNV) secundária a degeneração macular relacionada a idade (DMRI) com ênfase especial a terapia fotodinâmica (PDT).

Métodos: Revisamos artigos publicados a partir de 1974 até 1999 relacionados a DMRI, seus tratamentos disponiveis e PDT.

Resultados: $O$ tratamento provadamente efetivo mais utilizado para CNV é fotocoagulação com laser o qual não apresenta um impacto expressivo na deficiência visual causada pela DMRI. Técnicas alternativas de prevenção e tratamento estão sob investigação incluindo cirurgias, tratamento farmacológico antiangiogênico e prevenção com fotocoagulação. PDT com Verteporfina demonstrou ser efetiva no fechamento de CNV em nosso modelo experimental. Um estudo clínico inicial demonstrou que uma aplicação única poderia estabilizar a área de CNV subfoveal com componente clássico na maioria dos pacientes por até 3 meses. Dados de 12 meses em tratamentos quadrimestrais revelaram que a estabilização da visão, significando melhora, não alteração ou perda de até 3 linhas ocorreu em $61,4 \%$ dos pacientes tratados e que estes eram menos susceptiveis a perda visual de 6 ou mais linhas (85\%) quando comparados com placebo (76\%). Outro estudo clínico está em andamento para analisar o PDT em CNV do tipo oculto.

Conclusão: O tratamento para esta devastadora patologia continua desafiador. Estes estudos clínicos demonstraram fechamento inicial do CNV com PDT e interessantes resultados em termos de acuidade visual, embora estes resultados necessitem de comprovação clínica a longo prazo. A terapia fotodinâmica é uma das mais promissoras novas tecnologias para o tratamento de CNV.

Palavras-chave: Terapia fotodinâmica; Degeneração macular relacionada a idade; Neovascularização de coróide.

\section{REFERENCES}

1. Ferris F, Fine SL, Hyman L: Age related macular degeneration and blindness due to neovascular maculopathy. Arch Ophthalmol 1984;102:1640-2.

2. Rosenberg T, Klie F: The incidence of registered blindness caused by age related maculopathy. Acta Ophthalmol Scand 1996;74:399-402.

3. Dickinson AJ, Sparrow JM, Duke AM, Thompson JR, Gibson JM, 
Rosenthal AR. Prevalence of age related maculopathy at two points in time in an elderly British population. Eye 1997;11:301-14.

4. O'Shea J. Age related macular degeneration: A leading cause of blindness. Med J Aust 1997;165:561-64

5. Klein R, Wang Q, Klein BE, Moss SE, Meuer SM. The relationship of age related maculopathy, cataract and glaucoma to visual acuity. Invest Ophthalmol Vis Sci 1995;36:182-91.

6. Klein R, Klein BE, Jansen SC, Meuer SM. Five-year incidence and progression of age related maculopathy: The Beaver Dam eye study. Ophthalmology 1997;104:7-21.

7. Klein R, Klein BE, Linton K: Prevalence of age related maculopathy: The Beaver Dam eye study. Ophthalmology 1992;99:933-43.

8. Framingham eye study monograph: An ophthalmologic and epidemiological study of cataract, glaucoma, macular degeneration, and visual acuity in a general population of 2631 adults. Surv Ophthalmol 1980;24(suppl):335-610

9. Eye disease case control study group: Risk factors for neovascular age related macular degeneration. Arch Ophthalmol 1992;110:1701-8.

10. Bressler NM: Submacular surgery - Are randomized trials necessary? Arch Ophthalmol 1995;113:1557-60.

11. Macular Photocoagulation Study Group: Risk factors for choroidal neovascularization in the second eye of patients with juxtafoveal or sub-foveal choroidal neovascularization secondary to age-related macular degeneration. Arch Ophthalmol 1997;115:741-7.

12. Bressler SB, Maguire MG, Bressler NM, Fine SL and Macular Photocoagulation Study Group. Relationship of drusen and abnormalities of RPE to the prognosis of neovascular macular degeneration. Arch Ophthalmol 1990;108:1442-7.

13. Chandra SE, Gragoudas ES, Friedman E, Van Burskik EM, Klein ML. Natural history of disciform degeneration of the macula. Am J Ophthalmol 1974;78:579-82.

14. Chamberlain JA, Bressler NM, Bressler SB, Elman MJ, Murphy RP, Flood $\mathrm{TP}$ et al. The use of fundus photographs and fluorescein angiograms in the identification and treatment of choroidal neovascularization in MPS. The Macular Photocoagulation Study Group. Ophthalmology 1989;96:1526-34.

15. Macular Photocoagulation Study Group: Subfoveal neovascular lesions in agerelated macular degeneration: Guidelines for evaluation and treatment in MPS Arch Ophthalmol 1991;109:1242-57.

16. Stevens T., Bressler NM, Maguire MG. Occult choroidal neovascularization in age-related macular degeneration: A natural history study. Arch Ophthalmol 1997;115:345-50.

17. Macular Photocoagulation Study Group: Argon laser photocoagulation for senile macular degeneration: Results from a randomized clinical trial. Arch Ophthalmol 1982;100:912-8.

18. Macular Photocoagulation Study Group: Argon laser photocoagulation for neovascular maculopathy: Five-year results from randomized clinical trials. Arch Ophthalmol 1991;109:1109-14.

19. Macular Photocoagulation Study Group: Krypton laser photocoagulation for neovascular lesions of age-related macular degeneration: Results from a randomized clinical trial. Arch Ophthalmol 1990;108:816-24.

20. Macular Photocoagulation Study Group: The influence of the treatment extent on the visual acuity of eyes treated with Krypton laser for juxtafoveal choroidal neovascularization. Arch Ophthalmol 1995:113;190-4.

21. Macular Photocoagulation Study Group: Evaluation of Argon Green vs. Krypton Red for photocoagulation of subfoveal choroidal neovascularization in Macular Photocoagulation Study. Arch Ophthalmol 1994;112:1176-84.

22. Macular Photocoagulation Study Group: Laser photocoagulation of subfoveal neovascular lesions in age-related macular degeneration: results from a randomized clinical trial. Arch Ophthalmol 1991;109:1220-31.

23. Macular Photocoagulation Study Group: Laser photocoagulation of subfoveal neovascular lesions of age-related macular degeneration. Updated findings from two clinical trials. Arch Ophthalmol 1993;111:1220-9.

24. Schachat A: Management of subfoveal choroidal neovascularization. Arch Ophthalmol 1991;109:1217-8.

25. Macular Photocoagulation Study Group: Laser photocoagulation of subfoveal recurrent neovascular lesions in age-related macular degeneration: Results of a randomized clinical trial. Arch Ophthalmol 1991;109:10232-41.

26. Freund K, Yannuzzi LA, Sorenson JA: Age-related macular degeneration and choroidal neovascularization. Am J Ophthalmol 1993;115:786-91.

27. Gelfand Y, Linn S, Miller B: The application of Macular Photocoagulation Study eligibility criteria for laser treatment in age-related macular degeneration. Ophthalmic Surg Lasers 1997;28:823-7.
28. Macular Photocoagulation Study Group: Occult choroidal neovascularization: Influence on the visual outcome in patients with age-related macular degeneration. Arch Ophthalmol 1996;114:400-12.

29. Macular Photocoagulation Study Group: Subfoveal neovascular lesions in agerelated macular degeneration: Guidelines for evaluation and treatment in the Macular Photocoagulation Study. Arch Ophthalmol 1991;109:1242-57.

30. Macular Photocoagulation Study Group: Laser photocoagulation for neovascular maculopathy: Three-year results from a randomized clinica trial. Arch Ophthalmol 1986;104:694-701.

31. Macular Photocoagulation Study Group: Recurrent choroidal neovascularization after Argon laser photocoagulation for neovascular maculopathy. Arch Ophthalmol 1986:104;503-12.

32. Macular Photocoagulation Study Group: Persistent and recurrent neovascularization after laser photocoagulation for subfoveal choroidal neovascularization of age-related macular degeneration. Arch Ophthalmol 1994;112:489-99.

33. Macular Photocoagulation Study Group: Persistent and recurrent neovascularization after Krypton laser photocoagulation for neovascular lesions of age-related macular degeneration. Arch Ophthalmol 1990;108:825-31.

34. Mosseiev J, Alhalel A, Masuri R, Treister G.: The impact of Macular Photocoagulation Study results on the treatment of neovascular age-related macular degeneration. Arch Ophthalmol 1995;113:185-9.

35. Macular Photocoagulation Study Group: Results from a pilot trial. Arch Ophthalmol 1982;100:912-8.

36. Wetzig, P. Treatment of drusen-related aging macular degeneration by photocoagulation. Trans Am Soc Ophthalmol 1990;86:276-90.

37. Singelman J. Foveal drusen reabsorption a year after perifoveal laser photocoagulation. Ophthalmology 1991;98:1379-3.

38. Figueroa M, Regueras A, Bertrand J. Laser photocoagulation to treat soft drusen in age-related macular degeneration. Retina 1994;14:391-6.

39. Frenesson I, Nilsson S. Effects of Argon (Green) laser photocoagulation of soft drusen in early age-related macular degeneration. $\mathrm{Br} \mathrm{J}$ Ophthalmol 1995;79:905-19.

40. Little H, Showman J, Brown B. A pilot randomized controlled study on effect of laser photocoagulation of confluent soft macular drusen. Ophthalmology 1997; 104:623-31.

41. Sandberg M, Weiner A, Miller S, Gaudio A. High-risk characteristics of fellow eyes of patients with unilateral neovascular age-related macular degeneration. Ophthalmology 1998;105:441-7.

42. Gass J. Drusen and disciform macular detachment and degeneration. Arch Ophthalmol 1973;90:206-17.

43. Gass J. Photocoagulation of macular lesions. Trans Am Acad Ophthalmol Otolaryngol 1971;75:580-608.

44. The choroidal neovascularization prevention trial research group: Laser treatment in eyes with large drusen - Short term effects seen in a pilot randomized trial. Ophthalmology 1998;105:11-23.

45. Berger A, Conway M, Del Priore L, Walker R, Pollack J, Kaplan H. Submacular surgery for subfoveal choroidal neovascular membranes in patients with presumed histoplasmosis syndrome. Arch Ophthalmol 1997;115:991-6.

46. Bressler NM: Submacular surgery: New informations, more questions. Arch Ophthalmol 1997;115:1071-2.

47. Thomas MA, Grand M, Williams D, Lee C, Pesin S, Lome M. Surgical management of subfoveal choroidal neovascularization. Ophthalmology 1992;99:952-66.

48. Gass J. Biomicroscopic and histopathologic considerations regarding the feasibility of surgical excision of subfoveal neovascular membranes. Am J Ophthalmol 1994;118:285-98.

49. Thomas MA, Dickinson JD, Melberg NS, Ibanez HE, Dhaliwal RS. Visual results after surgical removal of subfoveal choroidal neovascular membranes. Ophthalmology 1994;101:1384-96.

50. Roth D, Downie A, Charles S. Visual results after submacular surgery for neovascularization in age-related macular degeneration. Ophthalmic Surg Lasers 1997;28:920-25.

51. Coscas G, Meunier I. Chirurgie des membranes neovasculaires sousretiniennes maculaires. J Fr Ophthalmol 1993;16:633-41.

52. Machmer R, Steinhorst U. Retinal separation, retinotomy and macular relocation: II. A surgical aproach for age related macular degeneration? Graefes Arch Clin Exp Ophthalmol 1993:231;635-41.

53. De Juan E, Lowenstein A, Bressler NM. Translocation of the retina for management of subfoveal choroidal neovascularization II: A preliminary report in humans. Am J Ophthalmol 1998;125:635-46.

54. De Juan E, Bressler NM, Loewnestein A, Hinz B. Limited retinal translocation follow up in 32 patients. Presented in age related macular 
degeneration meeting - Baltimore, June 1998

55. Peyman GA, Blinder KJ, Paris CL, Alturki W, Nelson NC Jr, Desai U. A technique for retinal pigment epithelium transplantation for age-related macular degeneration secondary to extensive subfoveal scarring. Ophthalmic Surg 1991;22:102-8.

56. Algvere P, Berglin L, Gouras P, Sheng Y. Transplantation of fetal retinal epithelium in age related macular degeneration with sub foveal neovascularization. Graefes Arch Clin Exp Ophthalmol 1994;232:707-16.

57. Kaplan HJ, Tezel TH, Berger AS, Wolf ML, Del Priore LV. Human photoreceptor transplantation in retinitis pigmentosa: A safety study. Arch Ophthalmol 1997;115:1168-72.

58. Chakravarthy U, Houston R, Archer D. Treatment of age related subfoveal neovascular membranes by teletherapy: A pilot study $\mathrm{Br} \mathrm{J}$ Opthalmol 1993;77:265-73.

59. Bergink GJ, Deutman AF, van de Broek JF, van Dael WA, van der Maazen RW. Radiation therapy for subfoveal choroidal neovascular membranes in agerelated macular degeneration: A pilot study. Graefes Arch Clin Exp Ophthalmol 1994;103:878-99.

60. Finger P, Berson A, Sherr D, Riley R, Balkin R, Bosworth J. Radiation therapy for subretinal neovascularization. Ophthalmology 1996;103:879-89.

61. Spaide RF, Guyer DR, McCormick B, Yannuzzi LA, Burke K, Mendelsohn $\mathrm{M}$, et al. External beam radiation therapy for choroidal neovascularization. Ophthalmology 1998;105:24-30.

62. Stalmans P, Leys A, Limbergen E. External beam radiotherapy (20 Gy - 2 Gy fractions) fails to control the growth of choroidal neovascularization in agerelated macular degeneration: A review of 111 cases. Retina 1997;17:481-92.

63. White C, Sonheimer H, Crouch E, Wilson H, Fan L. Treatment of pulmonary hemangiomas with recombinant interferon Alpha-2a. N Engl J Med 1989;320:1197-200.

64. Ezekowitz R, Mulliken J, Folkman J. Interferon alpha 2-a therapy for lifethreatening hemangiomas of infancy. N Engl J Med 1992;326:1456-63.

65. Miller JW, Stinson W, Folkman J: Regression of iris neovascularization with systemic alpha-interferon. Ophthalmology 1993;100:9-14.

66. Pharmacological therapy for macular degeneration study group. Interferon alpha 2-a is ineffective for patients with choroidal neovascularization secondary to age related macular degeneration. Arch Ophthalmol 1997;115:865-72.

67. D'Amato R, Loughnan M, Flynn E, Folkman J. Thalidomide is an inhibitor of the angiogenesis. Procl Natl Acad Sci USA 1994;91:4082-5.

68. Ip M, Gorin M. Recurrence of choroidal neovascular membranes in a patient with punctate inner choroidopathy treated with daily doses of thalidomide. Am J Ophthalmol 1996;122:594-5.

69. Aiello LP. Vascular endothelial growth factors and the eye: Biochemical mechanisms and implications for novel therapies. Ophthalmic Res 1997:29;354-62.

70. Husain D, Ryan A, Cuthbertson R, Miller JW, Adamis AP. Vascular endothelial growth factor expression is correlated with choroidal neovascularization in a monkey model. Invest Ophthalmol Vis Sci 1997;38:s501.

71. Miller JW, Adamis AP, Shima DT, D'Amore PA, Moulton RS, O'Reilly MS et al. Vascular endothelial growth factor/permeability factor is temporally and spatially correlated with ocular angiogenesis in a primate model. Am J Pathol 1994; $145: 572-8$.

72. Crum R, Szabo S, Folkman J. A new class of steroids inhibits angiogenesis in the presence of heparin or a heparin fragment. Science 1985;230:1375-8.

73. O'Reilley MS, Holmgreen L, Shing Y, Chen C, Rosenthal RA, Moses M et al. Angiostatin: A novel angiogenesis inhibitor that mediates the supression of metastasis by a Lewis lung carcinoma. Cell 1994;79:315-28.

74. O'Reilley MS, Boehm T, Shing Y, Fukai N, Vasios G, Lane WS et al. Endostatin: An endogenous inhibitor of angiogenesis and tumor growth. Cell 1997;88:277-85.

75. Daniell M, Hill J.: A history of photodynamic therapy. Aust N Z J Surg 1991;61:340-8.

76. Spikes J. Photodynamic action: From the paramercium to the photochemoterapy. Photochem Photobiol 1997;65:142-7.

77. Dougherty TJ, Gomer CJ, Henderson BW, Jori G, Kessel D, Korbelik M et al. Photodynamic Therapy: Review. J Natl Cancer Inst 1998;90:889-905.

78. Raynolds T. Photodynamic therapy expands its horizons. J Nat Cancer Inst 1997;89:112-4.

79. Stables G, Ash D. Photodynamic therapy. Cancer Treat Rev 1995;21:311-23

80. Rowe P. Photodynamic therapy begins to shine. Lancet 1998;351:1496.

81. Jin M, Yang B, Zhang W, Wang Y. Photodynamic therapy for upper gastrointestinal tumors over the past 10 years. Semin Surg Oncol
1994;10:111-3

82. Schumaker B, Lutz M, Hotzel F. Practical clinical use of laser photodynamic therapy in the treatment of bladder carcinoma in situ. Lasers Med Sci $1986 ; 1: 257$

83. Nseyo U, Dougherty T, Sullivan L. Photodynamic therapy in the management of resistant lower urinary tract carcinoma. Cancer 1987;60:3113.

84. Nishioka N. Drug, Light and Oxygen: A dynamic combination in the clinic. Gastroenterology 1998;114:604-6.

85. North J, Neyndorf H, Levy J. Photosensitizers as virucidal agents. J Photochem Photobiol 1993;17:99-108.

86. Wainwright M. Photodynamic antimicrobial therapy. J Antimicrob Chemother 1998;42:13-28.

87. Gossner L, Stolte M, Sroka R, Rick K, May A, Hahn EG et al. Photodynamic ablation of high-grade dysplasia and early cancer in Barret's esophagus by means of 5-aminolevulinic acid. Gastroenterology 1998;114: 448-55.

88. Taber S, Fingar V, Wieman T. Photodynamic therapy for palliation of chest wall recurrence in patients with breast cancer. J Surg Oncol 1998;68:209-14.

89. Bissonnette R, Lui H. Current status of photodynamic therapy in dermatology. Derm Clin N Am 1997;15:507-18.

90. Husain D, Miller JW. Photodynamic therapy of neovascular age related macular degeneration. Semin Ophthalmol 1997;12:14-25.

91. Young LH, Howard MA, Hu LK, Kim RY, Gragoudas EG. Photodynamic therapy of pigmented choroidal melanomas using a lipossomal preparation of benzoporphyrin derivative. Arch Ophthalmol 1996;114:186-92.

92. Henderson B, Dougherty T. How does photodynamic therapy works ? Photochem Photobiol 1992;55:931-48.

93. Boyle R, Dolphin D. Structure and biodistribution relationships of photodynamic sensitizers. Photochem Photobiol 1996;64:469-85.

94. Allison B, Pritchard P, Levy J. Evidence for low-density lipoprotein receptormediated uptake of benzoporphyrin derivative. Br J Cancer 1994;69:833-9.

95. Roberts W, Hasan T. Role of neovasculature and vascular permeability in the tumor retention of photodynamic agents. Cancer Res 1992;52:924-30.

96. Ochsner M. Photophysical and photobiological process in the photodynamic therapy of tumors. J Photochem Photobiol B: Biol 1997;39:1-18.

97. Girotti A. Photodynamic lipid peroxidation in biological systems. Photochem Photobiol 1990;51:497-509.

98. Wustrow T. Mechanisms of phototoxic effects in photodynamic therapy. Adv Otorhinolaryngol 1995;49:31-5.

99. Ferraudi G, Arguello H, Ali H, Van Lier J. Types I and II sensitized photooxidation of aminoacids by phthalocyanines: A flash photochemical study. Photochem Photobiol 1988;47:497-509.

100.Moan J, Boye E. Photodynamic effect on DNA and cell survival of human cells sensitized by hematoporphyrin. Photochem Photobiol 1981;2:301-7.

101.Fingar V, Wieman T, Wiehle S, Doak K. Relationship of vessel constriction, vessel leakage and release of vasoactive substances in photodynamic therapy. Photochem Photobiol 1991;53:100S-101S.

102.Reddi H. Role of delivery vehicles for photosensitizers in photodynamic therapy of tumors. J Photochem Photobiol B: Biol 1997;37:189-95.

103.Haimovici R, Kramer M, Miller JW, Hasan T, Flotte T, Gragoudas ES. Localization of the lipoprotein-derived benzoporphyrin derivative in the rabbit eye. Curr Eye Res 1997;16:83-90.

104.Kramer M, Miller JW, Delori F, Kenney A, Gonzalez V, Gragoudas ES Imaging of choroidal neovascularization by lipossomal BPD-MA angiography. Unpublished data.

105.Kramer M, Miller JW, Michaud N, Moulton RS, Hasan T, Flotte TJ, Gragoudas ES. Lipossomal Benzoporphyrin derivative verteporfin photodynamic therapy: Selective treatment of choroidal neovascularization in monkeys. Ophthalmology 1996;103:427-38.

106. Miller JW, Walsh AW, Kramer M, Hasan T, Michaud N, Flotte TJ et al. Photodynamic therapy of experimental choroidal neovascularization using lipoprotein derived benzoporphyrin. Arch Ophthalmol 1995;113:810-8.

107.Husain D, Miller JW, Michaud N, Connolly EJ, Flotte TJ, Gragoudas ES.: The effect of intravenous infusion using lipossomal benzoporphyrin derivative verteporfin for photodynamic therapy of experimental choroidal neovascularization. Arch Ophthalmol 1996;114:978-85.

108. Husain D, Kramer M, Kenney A, Michaud N, Flotte TJ, Gragoudas EG, Miller JW. Effects of photodynamic therapy using verteporfin on experimental $\mathrm{CNV}$ and normal retina and choroid up to seven weeks after treatment. Invest Ophthalmol Vis Sci. 2000, in press. 
109.Reinke M, Canakis C, Husain D, Michaud N, Flotte TJ, Gragoudas EG, Miller JW. Verteporfin photodynamic therapy retreatment of normal retina and choroid in the Cynomolgus monkey. Ophthalmology, 2000, in press.

110.Miller JW, Lane AM, Reinke M, Theodossiadis R, Gragoudas EG. Comparison of fluorescein angiography and indocyanine green angiography after photodynamic therapy for choroidal neovascularization. Invest Ophthalmol Vis Sci 1998;39:s242.

111.Schmidt-Erfurth U, Miller JW, Sickenberg M, Pournaras CJ, Laqua H, Barbazetto I et al. Photodynamic therapy of subfoveal choroidal neovascularization in a phase I/II trial study: Preliminary results of multiple treatments. Invest Ophthalmol Vis Sci 1997;38:s17.

112.Miller JW, Husain D, Levy J, Gragoudas EG, Schmidt-Erfurth U, Sickenberg $\mathrm{M}$, et al. Photodynamic therapy for macular degeneration using lipossomal benzoporphryn derivative. Invest Ophthalmol Vis Sci 1996;37s223.

113.Schmidt-Erfurth U, Miller JW, Sickenberg M, Pournaras CJ, Laqua H, Barbazetto I et al: Photodynamic therapy of subfoveal choroidal neovascularization: Clinical and angiographic examples. Graefes Arch Clin Exp Ophthalmol 1998;236:365-74.
114.Sickenberg M, Schmidt-Erfurth U, Miller JW, Donati G, Bressler NM, Zografos L et al. Preliminary results of photodynamic therapy for choroidal neovascularization in pathological myopia, ocular hystoplasmosis syndrome and idiopathic causes within a phase I/II study. Invest Ophthalmol Vis Sci 1997;38:s92.

115.Miller JW, Schmidt-Erfurth U, Sickenberg M, Pournaras CJ, Laqua H, Barbazetto I et al. Photodynamic Therapy for CNV Due to Age-related Macular Degeneration with verteporfin: Results of a single treatment in a phase I and II study. Arch Ophthalmol 1999;117:1161-73.

116.Schmidt-Erfurth U, Miller JW, Sickenberg M, Laqua H, Barbazetto I, Gragoudas EG et al. Photodynamic therapy for CNV due to age-related macular degeneration with verteporfin: Results of retreatments in a phase I and II study. Arch Ophthalmol 2000, In press.

117.Treatment of Age-related Macular Degeneration with Photodynamic Therapy (TAP) Study Group. Verteporfin (Visudyne TM) therapy of subfoveal CNV in age-related related macular degeneration. One year results of two randomized clinical trials - TAP report \#1. Arch Ophthalmol 1999;117:1329-45.

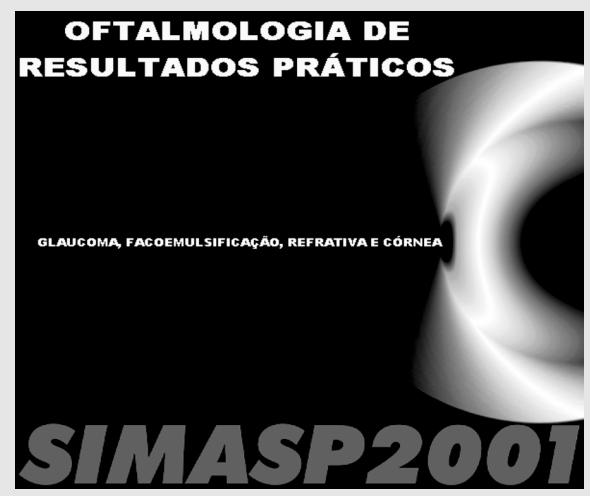

\section{SIMASP 2001}

Este Ano a Escola Paulista

ocupará a Av. Paulista,

o maior Centro Empresarial do Brasil.

Apresentaremos cursos realmente práticos e com aplicação imediata ao oftalmologista confira em nosso site...

\section{5 a 17 de Fevereiro de 2001 Club Homs Convention Center Av. Paulista, 735 - SP}

\section{Consulte informações em nosso site: www.ceo.org.br/simasp}

INFORMAC̣ÕES E INSCRIC̣ÕES: BACKGROUND Consultoria em Eventos

Fone: SIMASP: (1 1) 4034-4782

e-mail: background@sti.com.br 